\title{
Why Are Modern Bureaucracies Special? State Support to Private Firms in Early Eighteenth-Century France
}

\author{
Jean Beuve, Eric Brousseau, and Jérôme SGard
}

The Bureau du Commerce allocated rights and rents to private entrepreneurs via a mix of hierarchical division of labor and peer-based collegial deliberation. This set-up reflected an attempt to maximize information and expertise, but also allowed for the recognition of private rights and social interests. The opinions voiced within the Bureau (for or against each demand), and the qualitative arguments brought forward during the procedure, are robust predictors of eventual decisions. We see this result as an indication that impersonal, rational and informed decisionmaking could be obtained even within a patrimonialist, rent-seeking State.

W

hy do we see early modern bureaucracies as a major institutional and political innovation? And why are these experiments still framed today as the very beginning of modern statecraft? The paradox here is that most historians agree that these bureaucracies were primarily about social control, fiscal extraction, and military mobilization. This is why, presumably, they became a key asset for absolute monarchs intent on centralizing domestic power and extending their geopolitical reach. Hence our question: Can we reconcile the dark story of bureaucratic absolutism with the account of far-reaching innovations in administrative governance and policy-making? Did early organizational patterns foreshadow how these bureaucracies would work later, under regimes where private rights and democratic accountability would be embedded?

The most common answer to this dilemma contends more or less explicitly that liberal settlements, as in post-1688 England, were strong enough to curb and control the oppressive potential inherent in any bureaucracy, early modern or contemporary (Brewer 1989). Hence, the

The Journal of Economic History, Vol. 77, No. 4 (December 2017). C The Economic History Association. All rights reserved. doi: 10.1017/S0022050717001061

Jean Beuve is Assistant Professor, University of Paris, 1 Panthéon Sorbonne, Maison des Sciences Economiques - Univ. Paris 1, 106 Boulevard de l'Hôpital, 75013 Paris, France. E-mail: jeanbeuve@yahoo.fr. Eric Brousseau is Professor, Université Paris-Dauphine, PSL Research University, CNRS, UMR 7088, DRM, Place du Maréchal de Lattre de Tassigny, 75775 Paris Cedex 16, France. E-mail: eric@brousseau.info. Jérôme Sgard is Professor, Sciences Po, Centre de Recherches Internationales (CERI), CNRS, Paris, France. E-mail: jerome.sgard@sciencespo.fr.

Eric Brousseau benefitted from the support of the Governance and Regulation Chair at the University Paris Dauphine. Jérôme Sgard gratefully acknowledges the financial support of the Scientific Advisory Board of Sciences Po. 
difference between the eighteenth century English and French public administration would primarily be based on the external control to which they were subjected, that is, their Principal/Agent relationship and more generally the broader political and constitutional regime that controlled the state machinery.

This article proposes a different, though complementary, view that starts from Alexis de Tocqueville's classic 1859 essay, in The Old Regime and the Revolution: the transition to a modern, law-based, bureaucratic state did not result only from regime change, but also from a long-term process of administrative centralization and procedural rationalization (Tocqueville 2012). Consistency in decision-making and impersonalitytreating "everybody the same"-could thus emerge from a bottom-up, practical concern for effectiveness that can already be observed in an absolutist context. Critically, we defend that early bureaucracies (or parts of them) were able to recognize the plurality of social interests and private rights, the necessity to address issues of incentives and the concern for informational asymmetries, hence for expertise. While these modern patterns long remained marginal or interstitial, they also showed substantial resilience and dynamism: small and discrete shifts, pragmatic innovations, and ad hoc responses to individual problems or crises may have been the source of enduring efficiency gains in bureaucratic work. There is no reason indeed why absolutist monarchs would have always rejected such improvements and the possibility of subsequent benefits. Later, radical reformers may have also drawn on these experiments in an explicit attempt to modernize and streamline the overall state administrations.

The Bureau du Commerce, on which we focus, was indeed a small, meritocratic, and rather modern agency within the French Ministry of Finance (known as the Contrôle Général des Finances). From the very first years of the $18^{\text {th }}$ century and till the Revolution it was in charge of commerce (domestic, foreign, and colonial) and the supply side (guilds, manufactures, etc.). On this latter count, and among many other tasks, it investigated and administered demands for state support, or privileges, that were voluntarily submitted by private entrepreneurs. In an economy that was primarily regulated at the local level, obtaining an enforceable legal status from the State administration was first a way to circumvent the closed networks of municipal authorities and guilds. But the Bureau de Commerce also handed out tax exemptions or production monopolies to chosen firms, so as to foster economic development. In this sense, it implemented an early form of industrial policy, broadly based a mercantilist world-view (Beuve, Brousseau, and Sgard 2017). 
What makes this agency remarkable is its rule-based, open-ended, deliberative approach to decision-making. Each application by entrepreneurs was discussed on a horizontal, peer basis within two colleges that mobilized a diverse set of competencies and interests, both from inside and outside the state administrations. The diversity of perspectives maximized the chance that all dimensions of each project would be taken into account, including the rights of competitors or the concern for scarce local resource, like wood or fresh water. But this procedure also allowed for a strong degree of mutual control between members of the two colleges, based on adhesion to a common argumentative language. A participant who argued in favor of his city of origin, for instance, had to justify why an exception to the rules and to accepted criteria of evaluation was warranted. Significantly, the fact that, with only one exception, the Minister endorsed the Bureau' proposals signals that he trusted the procedure per se.

By chance, the investigative work and the minutes of the meetings held at the Bureau, as well as the records of its final decisions, have survived in the French national archives. ${ }^{1}$ For the period 1724-1744, we have been able to retrieve the key elements in 267 files representing 95 percent of the cases. These individual files typically add up to tens of pages and attest to the substantial collective effort that was invested in these procedures. We have thus been able to code not only the details of the initial demands and the final decisions, but also a large part of the deliberations that took place in-between. In other words, we opened up the proverbial black box of decision-making and built a database that makes possible a minute exploration of the logic of deliberations within the Bureau and how, in practice, relative impersonality was obtained. We also provide evidences that the risk of self-selection by applicants were negligible.

Our results show that the respective opinions of each key voice (for or against a given application) and its stated substantive justification as expressed during the procedure are both significant predictors of the final decisions. Hence, the de jure and the de facto rules were broadly aligned, in a situation where erratic decision making, corruption and other forms of outside influence could have held sway. We take these results as an indication that this small agency, located at the core of the sprawling, patrimonialist, French monarchy, was able to follow a formal, means-end rational procedure and to deliver consistent decisions over a period of

\footnotetext{
${ }^{1}$ The papers of the Bureau de Commerce are in division F12/ items 1 to 724; the papers of the Contrôle Général des Finances that relate to this research are in division $\mathrm{F}^{7} / 1691$ and $\mathrm{F}^{7} / 1693$.
} 
21 years. Rule-based, impersonal governance could thus emerge and be consolidated within the state bureaucracy several decades before regime change triggered a root-and-branch modernization. We do not want to suggest however that this experience was formative in how the post Revolution administration was structured. We only observe isomorphic patterns. By the same token, whether the Bureau' policies had an observable impact on the economic development is a question on which we have no answer, explicit or implicit.

\section{POLICY-MAKING AND BUREAUCRACY IN ANCIEN REGIME FRANCE}

\section{Absolutism and Modernization}

Few authors deny that absolutist states were essentially about fiscal extraction and coercion, both domestic and external. The point was most clearly stated by Charles Tilly (1990, p. 14) in his classic work where he placed "the organisation of coercion and preparation for war squarely in the middle of the analysis" of how states developed and competed against each other across Europe. In this view, what ultimately differentiated the winners (like France, Prussia, or Sweden) and losers (like Burgundy, Scotland, or Poland) was the capacity to develop the new technology of bureaucratic absolutism. ${ }^{2}$ This new centralized state machinery, which was explicitly anchored on the executive power rather than on local authorities or the courts, became the place where principles of meritocracy and impersonality emerged and expanded. This classic theme was developed, among many others, by Otto Hintze (1975 [1919]) and Joseph Strayer (1970). ${ }^{3}$ But Max Weber also had it in mind when he proposed his ideal-typical, functionalist analysis of modern bureaucracies:

\footnotetext{
"The decisive reason for the advance of bureaucratic organization has always been its purely technical superiority over any other form of organization. The fully developed bureaucratic apparatus compares with other organizations exactly as does the machine with the non-mechanical modes of production." (Weber 1978 [1920], p. 973).
}

\footnotetext{
${ }^{2}$ We use here the terms "bureaucracy" and "bureaucrat" in an entirely non-normative acception, hence without any kind of implied (negative) value judgment. The term "civil service" connotes the individual personnel more than the organization as a whole. "Administration" or "public administration" is probably less often used in the social sciences than bureaucracy, though we use both terms as synonyms here.

${ }^{3}$ A similar argument has been developed by authors as diverse as Finer (1997), Spruyt (1994), and Hoffman (2015); but see also macro-societal or post-Marxian historians like Moore (1966), Skocpol (1979), and Wallerstein (1980).
} 


\section{Economic Policy-Making under the Ancien Regime and} the Rationale for Privileges

What was probably unique in the French case was the complex interplay between, respectively, the trends towards political and bureaucratic centralization and, before 1789, the country's intense legal, institutional, and social fragmentation. Peasants, merchants, aristocrats, or priests did not have rights in the modern, impersonal sense; instead, their individual franchise was primarily defined by their belonging to status groups, like estates. But civil life was also regulated by customary laws, which were thoroughly fragmented across the country. Both the 65 coutumes générales and the more than 300 other coûtumes locales were all enforced by the local courts, and ultimately by the 14 regional appellate courts (or Parlements). This assemblage was the legacy of the century-long process through which the monarchy had aggregated a large and heterogeneous set of cities, counties, provinces, and kingdoms that all kept much of their political and legal institutions.

A major implication was that the scope for across-the-board impersonal policies, which would affect all agents in a symmetric way, was very limited. The King could wield extreme, possibly lethal, powers against individual persons, who could be sent to the Bastille or invited to Versailles. He could also spend resources and project force by building roads and canals or by repressing rural uprisings. Yet, in general, the state had at most a limited capacity to "govern society" or "the economy" as a whole insofar as it could have tried to influence how the representative individual behaved in matters of investment decisions or technical innovations. In fact, this representative subject did not exist.

As it tried to regulate the economy, the public administration thus relied on privileges, an ad hoc legal instrument whereby, in our case, the King granted a specific package of franchises and benefits to a given entrepreneur. But privileges could also be issued in favor of a guild, a city, or a crony. Jeff Horn (2015) stresses that privileges were not only the instrument for the allocation of rents. They could also be used to free merchants and entrepreneurs from the shackles of a conservative social order, so they could innovate and trade more easily. In many respects, this is what the Bureau tried to do when granting ad hoc privileges to selected manufacturers, a practice that belongs quite clearly to what Michel Foucault (2004) calls governmentality. 


\section{The Contrôle Général des Finances: An Emerging Modern Bureaucracy}

The attempt to develop embryonic forms of public policies originated primarily in the Ministry of Finance, or Contrôle Général des Finances, of which the Bureau de Commerce was a part. ${ }^{4}$ Early on during the $17^{\text {th }}$ century, the Contrôle developed its own body of civil servants and a specific territorial network that cut across local allegiances and seigniorial jurisdictions. At the level of the province, its main administrator was the Intendant, who was, therefore, the key intermediary between local interests and the Parisian bureaucracy. Overall, the Contrôle Général was a rather small organization. Joël Felix (1997) estimates that the headquarters in Paris had a staff of about 100-110 persons by the 1770s, and around 150 by 1789; the local network in the provinces would have totaled some 540 people by mid-century. Within this total, 20 to 25 top bureaucrats, experts and secretaries worked in Paris for the Bureau $d u$ Commerce. ${ }^{5}$

The modern character of the Contrôle Général should not be overstated. Patronage and corruption were widespread and considered normal to some extent (Bossenga 1991; Campbell 1996; Kettering 1986; Mousnier 1982). Many positions in the local and central administrative machinery were farmed out, hence they did not entail a direct hierarchical relationship or an easy capacity to organize collective work around impersonal principles. ${ }^{6}$ Top officials from the administration also hired a large proportion of their own staff directly: hence they empowered their staff, rather than being empowered by them.

The key question we address here is whether the Bureau in particular had the capacity to handle its substantial portfolio in a consistent manner;

\footnotetext{
${ }^{4}$ Within the extensive literature on the Ministry of Finance under the Ancien Regime, one may consult, for instance, Antoine (1973, 2003), Bosher (1970) and the edited volume of the Comite pour l'histoire économique et financière de la France (1997).

${ }^{5}$ The literature on the Bureau is not very extensive. Early studies, of good quality, have been published by d'Origny (1857), Biollay (1885), Bonnassieux (1900), and Wybo (1936). Beyond these, one of the best references is Schaeper (1983), who covers the first 15 years of existence of the Bureau, then Parker (1979) who looks at its two last decades before the Revolution. Vosgien (2017) is a recent addition. Minard (1998) presents a comprehensive review on the control of manufactures and the corps of Inspecteurs des manufactures. On the distribution of privileges to entrepreneurs and their legal construction the main reference is Horn (2015).

${ }^{6}$ On the specific dimension of the administrative work, the recruitment and division of labor at the Ministry of Finance, please see for Ricommard (1962, 1963) Bosher (1964), Felix (1997) and Garrigues (1998); on the Commis as the forerunners of modern bureaucrats, see Felix (1997) and Antoine (2003).
} 
that is whether its modern features supported a decision process that was broadly stable, impersonal and means-end rational. In practice, decisions could have been entirely erratic due to systematic inconsistency in bureaucratic work and sheer lack of information. Alternatively, as argued for instance by Eric Szulman (2011) and Frédéric Graber (2011) in the case of public infrastructures, policy decisions might have resulted from tactical games between cliques and coteries, either at the court or in the provinces. This picture would support the even more radical analysis of Robert Ekelund and Robert Tollison $(1981,1989)$ or Hilton Root (1994), who see the state machinery of the period as a grand rent-extracting organization, whose only aim was to maintain social control and consolidate the monarchy.

\section{THE BUREAU DE COMMERCE AND ITS DECISION-MAKING PROCESS}

Remarkably, the answer to these well-perceived threats did not take the form of hyper-centralization and social insulation. On the contrary, the procedure followed at the Bureau was explicitly pluralist, informationdriven and impersonal. At its core we find two colleges that successively discussed each submission on a peer basis, before adopting a consensus opinion that was eventually submitted to the Minister, together with explicit justifications. ${ }^{7}$ In all cases in our database, except one, the Minister endorsed the proposition, signaling, therefore, that he trusted the procedure as such rather than the personal view of each individual participant. ${ }^{8}$

\section{Two Colleges of Merchants and Top Bureaucrats}

The first college in the Bureau du Commerce was made up of ten to 14 Députés du Commerce. These were well-established, experienced merchants who generally operated outside the guilds and across the local markets and jurisdictions, most often in banking, foreign trade, and occasionally the slave trade. Hence, they had a good knowledge of existing technologies and products, market practices (including the old Law Merchant), and the economic geography of both the kingdom and foreign countries. Most of them also had some experience of civil service

\footnotetext{
${ }^{7}$ Over the period under review, all three successive Contrôleurs Généraux followed this rule.

${ }^{8}$ Max Weber discusses in general terms the role of "advisory colleges" in early modern monarchies, primarily in matters of finance and taxation. See Weber (1978 [1920], vol. I, pp. 277 and 280). See also Waters $(1989,1993)$ on this passage. References to colleges in earlymodern states are also found in Strayer (1970), Cosandey and Descimon (2002), and Hintze (1975 [1919]). Please also see Lazega (2001) for a sociological analysis in a contemporary setting.
} 
before joining the Bureau, typically in municipal government or in the local elected traders' courts. Being appointed to the Bureau, through a process mixing election by the local Chambers of Commerce and confirmation or cooptation by the Contrôle Général, was for most of them a crowning achievement. Though they did not become formal members of the administration, access to decision-makers and the relative proximity to the King brought them a unique social status. Most of them thus stayed in the Bureau until retirement or death; returning to the province and to the limited honors offered by municipal life was not a very attractive proposition. Sustained flows of correspondence, memorandums and briefs between cities and their Députés suggest as well that expert work came before the defense of local interests. ${ }^{9}$ While they could write, for instance, a dissenting opinion on a given decision, this was a rare occurrence in the case of the privilège to firms. And contrary to what their name suggests, nothing in the way the Députés addressed the King's men signals the authority or the political legitimacy of elected representatives. They argued in the name of "the good of commerce," which was framed as a fully legitimate aspect of the public good, or of "the good of the kingdom" (Kessler 2007; Smith 1995).

After the group of Députés, the second advisory college was organized around the head of the Bureau de Commerce and his four main assistants, who made up the permanent backbone of this agency. They were either ennobled or of noble origin, though they were not elite courtiers or aristocrats. They had typically entered public service at a young age and were engaged in a lifetime career, marked by a succession of diverse positions that would (hopefully) take them ever closer to the King. This certainly created an esprit de corps and strong incentives to show diligence, expertise, and a commitment to the bureaucratic process as such. The only significant bifurcation in their career track was the option to move to the higher courts, such as the Parlement de Paris. But such a transition required that their track-record be impeccable.

These technocrats coordinated the investigative work and interacted on a daily basis with the rest of the Contrôle Général, with the other ministries, and with the provincial Intendants. They also took care of the ultimate implementation of decisions and kept detailed records on the daily work at the Bureau, which remain till today a key source of information. Thrice a month, these permanent officials met in full session with

\footnotetext{
${ }^{9} \mathrm{~A}$ lot of dissatisfaction, if not frustration, is indeed easy to observe in the correspondence of the municipal authorities and the chambers of commerce with "their" Député. Read Quenet (1978) on the Députés from Nantes, Labraque-Bordenave (1889) on the case of Bordeaux, Pariset (1887) for Lyon, and Fournier (1920) for Marseille.
} 
a set of high-level officials from other branches of government, with the Députés and a representative of the tax farms in attendance. ${ }^{10}$ This is the second college where the final proposal on privileges for manufactures was made.

This two-level procedure is remarkable on at least three counts. First, it was instrumental in ensuring that all possible sources of information had been mobilized before each case was decided. If at any point a critical element was seen missing, or if a significant stakeholder had not been consulted, the discussion could be postponed until the relevant information had been found. Second, the two colleges allowed for a large set of interests and professional competences to have, directly or indirectly, a voice in the process and thus to reveal underlying rights and technical considerations that an insulated bureaucracy might have overlooked. Third, this pluralist dimension could support a pattern of mutual monitoring between participants, based i.a. on common discursive rules and decision criteria. Individual participants thus had to defend their view within this argumentative language in order to convince the whole spectrum of experts and technocrats, against competing opinions.

This pluralist, information-based procedure thus reinforced the effect of the professional incentives and helped minimizing the impact of vested interests and of the social attributes of each applicants: his origin and social capital, his possible connection with political brokers, or the specific appeal of his project for a given constituency. In other words, the rules that governed the deliberation and the decision process were instruments for constructing impersonality in policy decisions.

\section{The Procedure for Granting Privileges}

This pattern is reflected in the successive steps that structured the deliberation process (see Figure 1). First, applications by individual entrepreneurs were made to the Bureau directly or were transferred to it by the Ministry of Finance and its agents in the provinces - the Intendants. ${ }^{11}$ Applications typically included a description of the project,

\footnotetext{
${ }^{10}$ Under the Ancien Regime, tax collection was outsourced or farmed out to groups of private financiers on the basis of long-term contracts. Over time, the Fermiers Généraux built powerful private bureaucracies with (also) a formal division of labour, strict hierarchy, life-long careers. Their representatives at the Bureau should thus be seen as agents of these private administrations.

${ }^{11}$ Smith $(1995,2002)$ argues that demands and cases submitted to the Bureau were typically prepared and sponsored by intermediaries with personal access to the ministry. Yet Smith's examples concern very few private entrepreneurs. Moreover, the very fact that applicants may have relied on advisors when preparing their submission does not, per se, negate the possibility of subsequent rational decision-making by the Bureau.
} 


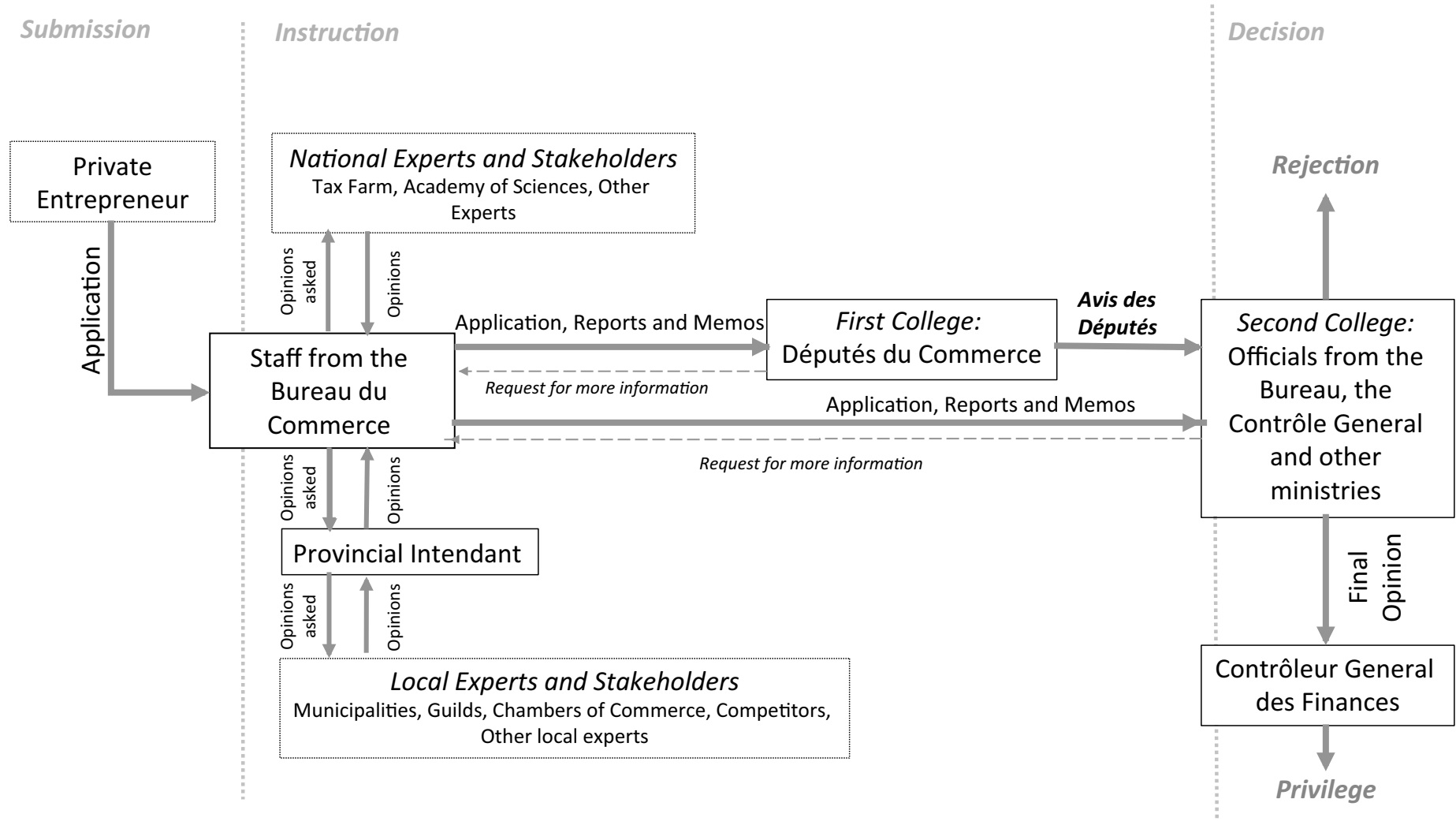

FIGURE 1

THE DECISION MAKING PROCESS OF THE BUREAU DE COMMERCE

Source: Authors' calculations. 
some technical details, considerations with respect to implementation, and indications regarding the professional background of the entrepreneur. They almost never included quantitative data, such as accounts, let alone forecasts. Rather, the entrepreneur justified his demand by alluding to substantial collective benefits, to the underlying investment risks and to similar projects that had already been supported in the past. He then established the list of the benefits he wanted.

A member of the Bureau's administrative staff then took over the application and asked for factual reports or the opinions of a more or less extended array of informants, stakeholders, or experts. The Provincial Intendant contributed to most cases and, as a rule, he consulted extensively with the municipal or provincial authorities, the local guilds, the chambers of commerce, or individual competitors. But the Bureau also regularly asked for the opinion of the tax farms (when tax cuts were claimed) or the Académie des Sciences (when the project was based on a claim of technical innovation).

Next, the applicant's written submission, together with all the respective reports and opinions, were sent to the Députés du Commerce, who discussed the case collectively. Unless further information was requested, a collective Avis summarized the case for and against and proposed whether to accept, reject, or curtail the demand.

Finally, a plenary meeting of the Bureau (i.e., the second deliberative college made up primarily of technocrats) took stock of the whole file, including the Avis des Députés, reviewed and discussed the case again and sent a final, unanimous proposal to the Minister (again, if no further investigation was requested). Alternately, if the application was rejected, only an internal record was kept, with no formal reporting to the Minister. As previously stated, in all case except one, the Minister confirmed the Bureau's position, which would then formalize this final decision under the form of a legally binding Lettre-Patente or Arrêt.

Taken as a whole, this procedure reflects a deliberation process that was not structured as a negotiation whereby competing parties would try to reach a compromise and balance their respective interests in a mutually satisfactory manner. Rather, the language used and the criteria for granting privileges were predicated on notions of due process, private rights, respect for precedents, and some idea of the common good. Provided a submission was not entirely rejected, the deliberation aimed in practice at tailoring each package of benefits to the specifics of each investment project and to its potential costs and benefits for the economy, local or national. 


\section{A Large Menu of Privileges}

A first set of benefits affected the business per se, as opposed to the person of the entrepreneur or the investors. The simplest and most widely shared one was a legal authorization to establish a self-standing business, outside the guilds. Property rights and market access were thus shielded against the pressures, or sometimes the direct attacks, of local guilds and competitors. In addition, the applicant could claim the higher status of a Manufacture or even a Manufacture Royale. This designation came with increased legal protection and social status, although, at the same time, this included the requirement to comply with specific regulations covering processes and products (Minard 1998).

A territorial exclusivity could also be granted. The right to mine, for instance, was generally limited to a rather narrow, well-delineated region, while inventions were protected across the whole kingdom (and so this privilege can be considered a proto-patent). In the case of manufacturers, these territorial exclusivities took the form of a production monopoly, a practice that has attracted a lot of critical attention (e.g., Ekelund and Tollisson 1981, 1989; Root 1994). Their extension was typically limited to 10 to 40 kilometers or, more rarely, to 1 of the 34 provinces. And while competitors could not establish plants or workshops within this zone, they could still enter the local market and sell their own products. The overall effect of such monopolies was often compounded by reduced tolls on inputs imported from other regions or from abroad, so that a large part of the overall package of benefits boiled down to the manipulation of net transportation costs.

Beyond, exemptions could target the income flow of the individual entrepreneur and his associates, an approach that was rightly seen as less distortionary than measures that affected the business per se and its cost structure. Cuts on income taxes (like la taille) or consumption taxes (e.g., on alcohol and tobacco) were the most common at this point. But skilled workers attracted from abroad could also be allowed to enter the kingdom free of tax and benefit from further ad-hoc fiscal advantages. Non-monetary benefits, such as exemption from billeting soldiers or from the obligation to serve in the local militia, were also on the menu. Last, straightforward public subsidies or Treasury loans were occasionally demanded, but even more rarely granted.

While these packages of benefits can be rationalized ex post as a response to the absence of a market for capital investment, the distortionary character of the instrument was clearly perceived. The Députés and the top administrators fully recognized that competition was the 
ultimate test of entrepreneurial success. ${ }^{12}$ Significantly, privileged firms remained entirely subjected to the 1673 Ordonnance sur le Commerce (an early commercial code), and in particular to its chapter on bankruptcy. We actually found several occasions when an entrepreneur proposed to take over a privilege that had been abandoned after its earlier holder had gone bankrupt.

The decision to support a firm was thus explicitly construed as an exception to an impersonal rule, not as the result of a deal between the parties, which might be later balanced off by a similar favor offered to another clientele. At stake were notions of rationality and consistency in decision making, but also of accountability vis-à-vis third parties, such as local stakeholders and competitors. Though formal checks and balances were weak under the Ancien Regime, the monarchy was keen to avoid confrontation with significant social interests, including provincial elites (Kettering 1986; Bossenga 1991; Campbell 1996).

\section{DATA AND EMPIRICAL STRATEGY}

\section{Encoding the Deliberation Process}

To test whether this complex machinery actually endowed the policymaking process with a tangible degree of overall consistency and meansend rationality, we mobilize the complete paper-track left over in the archives of the Bureau as each request moved through the system. We are thus interested in the bureaucratic process per se, not with the substantive policy aims that were followed or with the actual ex post effect of this policy.

Out of a total of 281 submissions received by the Bureau between 1724 and 1744, we have been able to identify and code the key features for 267 individual cases. ${ }^{13}$ In practice we focused on five documents: the reports of the Provincial Intendants, the Avis des Députés (i.e., the conclusions reached by the first college), the minutes of the deliberations at the Bureau (i.e., the second college), the final decision, and the Arrêt

\footnotetext{
${ }^{12}$ One example among many is this statement of the Députés du Commerce on one case: "It is quite possible that Monsieur Chatal has discovered a new way to thread cotton, (...). He should, thus, benefit from a strong competitive advantage and be, therefore, in a position to find associates" (1 August 1727).

${ }^{13}$ The difference between the 281 total investigated cases and the 267 decisions in our database is due to applications that were investigated by the Bureau for which we did not find any record of the final decision (14 cases). Generally, these are cases where the members of the Bureau considered that they did not have sufficient information and asked for further investigation. They are, thus, de facto refusals (since we were unable to identify related decrees granting privileges) but, since they do not show motivation, they cannot be included in our analysis.
} 
or the Lettre-Patente that formalized the privilege if the submission was not entirely rejected. Two hundred and fifteen files include an Avis des Députés, 136 a report by the provincial Intendants, and 111 files include both. Most commonly, the missing documents could have been lost or destroyed. In addition, the Intendants, for instance, were not consulted when the submission did not have any specific territorial dimension such as when a de facto patent was claimed. But some applications were rejected out of hand as extravagant, a judgment that can sometimes be confirmed even by a twenty-first century reader. Note on the other hand that because each key document typically restates the main elements of the case so far, losses can be partially compensated and a great degree of overall security assured when reconstructing how each submission was discussed.

On this basis, we first coded the main features of each submission, the benefits being asked and the justifications brought forward by the entrepreneur. Then we have the arguments leveraged by the Intendant and the Députés, for each characteristic claimed and for each benefit requested. Lastly, when encoding the final decision, we included the actual benefits that were given but also the characteristics of the project that the Bureau as a whole saw as valid justifications for granting this privilege. Each project is also identified by its location and jurisdiction, date of submission and industry or whether the project was entirely new or would support an already-existing enterprise. We also added dummies when the project concerned luxury goods (like lace or silk) and when an entrepreneur of foreign origin was involved.

\section{Selection Issues}

Our dataset covers 95 percent of the applications that reached the Parisian Bureau from 1724 to 1744 . Whether these applications were representative of the total population of entrepreneurs in the economy does not affect our discussion, because we do not focus on issues of overall policy efficiency or distributive fairness. Similarly, subjective or hidden motivations beyond the individual decision to apply for a privilege do not affect much our discussion. Neither is the possibility that brokers or patrons could offer advice of much consequence here. What we want to know is whether the Bureau processed the demands that reached it in a consistent, means-end rational, impersonal way. Hence, the key issue regarding selection is whether the decision to apply by individual entrepreneurs might have been affected by a perception that the Bureau' procedure was systematically biased or corrupt. If this had been the case, we might then infer that self-selection could have affected procedural 
outcomes and so our results. The problem of course is that we cannot observe the judgment of potential applicants on the Bureau: we may only infer indirectly that no such self-selection occurred in a systematic way.

First, when we examine the aggregate data, outcomes do not appear to have been easy to anticipate: 42.3 percent of submissions were fully accepted, 28.5 percent were rejected, and 29.3 percent were curtailed. Still, we controlled in the remaining correspondence of the key members of the Bureau for attempts at influencing the final decisions, directly or indirectly - including by the Minister. Several thousand letters and memos have been checked: only four letters clearly aimed at influencing the decision on given applications, but to no avail. We found no trace either that the King sought to bear on the discussions at the Bureau.

A further question is whether it was actually the only channel by which private entrepreneurs could obtain a privilege, hence that they could not bypass the Bureau. Again, we found no trace of such possibilities, for example under the form of a Lettre-Patente that would not have resulted from a procedure at the Bureau. An important element here is that, legally, all the privileges that were issued by the state administration stemmed from the King's will and were enforceable in court across the country. Hence protecting royal authority was per se a powerful motive for maintaining control over the issuance of privileges and making sure that quasi-substitutes could not be easily available, allowing for some kind of "forum-shopping."

It is also unlikely that the officials that ran the Bureau would have mobilized so many persons and working time into each case if they had good reasons to believe that the outcome was foretold. One should also remember at this point that this monarchy and its bureaucracy were not politically accountable. So the complexity of the Bureau procedure and the resource mobilized can hardly be accounted for by attempts to "window-dress" predetermined outcomes and offer justifications to a credulous public. In fact, there was no public whatsoever and no media calling the officials to account. The only person they addressed was the Minister, which is why his systematic endorsement of the Bureau' proposals is so significant: if he had thought that it could try to manipulate him, or that its process was intrinsically or even occasionally flawed, he would have not trust it so clearly. No Minister in any country wants to be seen as credulous. At Versailles, where a large part of the game over rents took place, it would have guaranteed instant political death. 


\section{Descriptive Statistics}

From a descriptive point of view, the projects submitted to the Bureau cover a rather large scope, including the mining sector, the paper, iron, and textile industries, and earthenware or glass production. But we also find services such as pumps for water provision, warehouses for longdistance traders, or transportation services. About 10 percent of the applications asked for de facto intellectual property rights on an innovation. ${ }^{14}$

We then observe that the Députés display prima facie a more restrictive bias as they more often recommend that demands be refused or curtailed: they fully approve 41.4 percent of cases while the Intendants have an approval rate of 65.4 percent. Table 1, which lists the arguments put forward by the Députés and Intendants respectively, as well as their frequency, also show that the provincial Intendants gave substantial weight to considerations about development of the local economy while the Deputés for instance focused more on the impact of the projects on the trade balance and pointed more often to adverse potential effects on competition. ${ }^{15}$ But these differences should not be overstated: among the seven arguments most frequently used by these two parties, five were shared by both. Hence, the two key parties to the decision rarely disagreed entirely: in only 5.4 percent of cases does one of them recommend rejection while the other argues for full approval.

More generally, there is no sign here of a systematic conflict between "reformers" and "conservatives," not to speak of free-marketers and centralizers, as has been sometimes defended in the literature on the Bureau de Commerce. ${ }^{16}$

\section{Estimation Strategy}

In order to move one step further in our understanding of how the Bureau worked, we now try to identify econometrically the determinants of its Final Decision $(F D)$. We distinguish the three main possible outcomes of

\footnotetext{
${ }^{14}$ Technological innovation came in two contrasting forms: either as a stand-alone submission or in the context of an industrial venture. In the former case, the applicant claimed an exclusive and tradable right to exploit his invention. Since the Bureau often considered the difficulties and obstacles to implementing such rights, the applicant could instead be awarded with a grant and his innovation would fall into the public domain.

${ }^{15}$ Definitions and summary statistics of all the variables used in the empirical analysis are provided in the Appendix.

${ }^{16}$ This evidence should indeed put to rest a longstanding debate on the ideological inclination of the Députés. In an early contribution, Cole (1943) argued that they favored consensus and continuity with the Colbertist legacy; conversely, Rothkrug (1965) and contends that the Députés were early "laissez-faire" militants who opposed the dirigiste tradition.
} 
TABLE 1

FREQUENCY AND RANKING OF THE JUSTIFICATIONS PUT FORWARD BY THE VARIOUS PARTIES IN THE DECISION

\begin{tabular}{|c|c|c|c|c|c|c|}
\hline Rank & $\begin{array}{l}\text { Final Decision } \\
\text { (267 Obs.) }\end{array}$ & & $\begin{array}{l}\text { Intendants } \\
\text { (136 Obs.) }\end{array}$ & & $\begin{array}{c}\text { Députés } \\
\text { (215 Obs.) }\end{array}$ & \\
\hline 1 & Quality+ & 30.3 & Local economy+ & 38.2 & Trade balance & 22.3 \\
\hline 2 & Trade balance & 27.3 & Quality+ & 30.1 & Consumer+ & 22.3 \\
\hline 3 & Local economy + & 24.7 & Trade balance & 25.7 & Quality+ & 22.3 \\
\hline 4 & Consumer + & 21.7 & Consumer+ & 23.5 & Restriction of competition & 21.9 \\
\hline 5 & Fixed costs & 16.5 & Valorization of local resources & 21.3 & Local economy+ & 20.0 \\
\hline 6 & Restriction of competition & 13.5 & Fixed costs & 17.6 & Absence of innovation & 16.3 \\
\hline 7 & Technical innovation & 13.1 & Restriction of competition & 11.0 & Technical innovation & 12.1 \\
\hline 8 & Valorization of local resources & 10.9 & Social employment & 9.6 & Fixed costs & 9.3 \\
\hline 9 & Absence of innovation & 10.5 & Attract labor force & 8.8 & Precedents - & 8.4 \\
\hline 10 & Social employment & 9.7 & Prior property rights infringement & 8.8 & Prior property rights infringement & 8.4 \\
\hline 11 & Precedents- & 7.9 & Risk of overproduction & 8.1 & Quality- & 7.4 \\
\hline 12 & Prior property rights infringement & 7.5 & Technical innovation & 7.4 & Valorization of local resources & 7.4 \\
\hline 13 & Risk of overproduction & 7.1 & Precedents + & 6.6 & Risk of overproduction & 7.4 \\
\hline 14 & Precedents + & 6.4 & Precedents - & 5.9 & Social employment & 7.0 \\
\hline 15 & Attract labor force & 6.4 & Fiscal costs & 3.7 & Industrial risk & 5.1 \\
\hline 16 & Quality- & 4.9 & Quality- & 2.9 & Uncertainty/incompleteness & 4.7 \\
\hline 17 & Uncertainty/incompleteness & 4.1 & Difficulty of implementation & 2.2 & Precedents + & 3.7 \\
\hline 18 & Difficulty of implementation & 3.7 & Absence of innovation & 2.2 & Fiscal costs & 3.7 \\
\hline 19 & Statutes and royal decrees - & 3.4 & Custom and common practices + & 1.5 & Difficulty of implementation & 3.3 \\
\hline 20 & Fiscal costs & 3.4 & Industrial risk & 1.5 & Consumer- & 2.8 \\
\hline 21 & Industrial risk & 3.0 & Custom and common practices - & 0.7 & Attract labor force & 2.8 \\
\hline
\end{tabular}




\begin{tabular}{lllllll}
22 & Reducing fraud & 2.6 & Local economy- & 0.7 & Lack of realization & 2.8 \\
23 & Lack of realization & 2.2 & Consumer- & 0.7 & Statutes and royal decrees - \\
24 & Statutes and royal decrees + & 1.9 & Provision of public good & 0.7 & Custom and common practices - & 2.3 \\
25 & Consumer- & 1.5 & Reducing fraud & 0.7 & Reducing fraud \\
26 & Custom and common Practices + & 1.1 & Fiscal fairness & 0.7 & Statutes and royal decrees + \\
27 & custom and common practices - & 1.1 & Lack of realization & 0.7 & Local economy- \\
28 & Local economy- & 1.1 & Uncertainty/incompleteness & 0.7 & Fiscal fairness \\
29 & Fiscal fairness & 1.1 & Statutes and royal decrees + & 0.0 & Custom and common practices + & 0.9 \\
30 & Provision of public good & 0.0 & Statutes and royal decrees - & 0.0 & Provision of public good & 0.5 \\
\hline
\end{tabular}

Notes: For each category of actors involved in the decision process (the Bureau for the Final Decision, applicants for the request, Intendants and Députés for their respective recommendations), we ranked the arguments they put forward according to their frequencies. For instance, while the recognition of benefits for the local economy is the most quoted by Intendants, Députés considered more often the (positive) impact on the trade balance.

Source: Authors' calculations. 
applications: they could be rejected ( 0$)$, they could be partially successful (1), or the entire set of privileges could be granted (2). We thus have an ordinal dependent variable $F D=\{0,1,2\}$. First, we explore how the Intendants and Députés respectively influenced the distribution of the final decision $(F D)$. The variables $I R$ (Intendants' Recommendation) and $D R$ (Députés' Recommendation) have been constructed in the same way as $F D$, depending upon whether the respective party recommends rejection, a partial grant, or a complete one. Therefore, $I R$ and $D R$ are also ordinal variables, with $I R=D R=\{0,1,2\}$. We use a generalized ordered logistic model (gologit hereafter) in order to assess the influence of each party on the final decision (Fu, 1998).

We thus begin with a set of tests to assess the respective influence of the Intendants and Députés on the likelihood of obtaining privileges:

$$
\begin{gathered}
P\left(F D_{i}>j\right)=\alpha_{i} I R_{i}+\beta_{i} D R_{i}+\gamma_{i} X_{i}+\varepsilon_{i} \quad \text { for } j=0,1 \\
P\left(F D_{i}>j\right)=\delta_{i} \text { Veto- } D_{i}+\mu_{i} \text { Veto- } I_{i}+\gamma_{i} X_{i}+\varepsilon_{i} \text { for } j=0,1,
\end{gathered}
$$

where $F D_{i}$ is the ordinal dependent variable for each individual demand $i, j$ is the number of decision categories and $\alpha$ and $\beta$ the two coefficients associated with Intendants' and Députés' recommendations (Equation $1)$. We then test for the presence of an implicit veto power by one or the other of these voices (Equation 2). The variable Veto-D is equal to 1 when the Députés recommend refusal while Intendants propose either a partial or an entire grant (five cases out of 111). Conversely, the variable Veto-I is equal to 1 when Intendants favor rejection while Députés call for a partial or an entire grant (also five cases out of 111). In both equations, $X_{i}$ is a vector of three control variables: Luxury is a discrete variable for privilege requests concerning luxury products; Foreigner is a discrete variable accounting for a demand made by a foreign entrepreneur, and Year stands for the date of the demand, to ensure that the results are not driven by time trends. We also include sector-group dummies. Fixed effects reflecting the regional dimension could not be included since there were 34 different provinces: province-dummies would have prohibitively reduced the degree of freedom of the gologit model. To limit the impact of this constraint and to account for potential heteroscedasticity and auto-correlation of error terms within geographical areas, we clustered the standard error at the regional level in all of our regressions.

The choice of generalized ordered logistic estimations was made in order to circumvent the issue of proportional-odds assumption. One of the assumptions underlying the ordered logistic model is that the "distances" between categories are equal. In our case, this principle would imply that 
switching from a rejection to a restricted set of privileges represents the same "step" in terms of decision-making as switching from a restricted set to the entire set of privileges. This hypothesis is a priori violated, if only because cuts from the initial demands to a curtailed set of benefits vary across cases. ${ }^{17}$

In a second set of estimations, we focus on how the qualitative arguments advanced during the final deliberations (second college) affect the collective decision, as sent to the Minister (Equation 3). We then analyze how the same arguments weigh, first on the respective recommendations of the Intendants and Députés (Equations 4 and 5), then on the final decision depending upon which of these two parties raised them (Equations 6 and 7). Hence, we run gologit estimates of the following five equations:

$$
\begin{gathered}
P\left(F D_{i}>j\right)=\alpha_{i} \text { BUREAUCRATS' ARGUMENTS }+\beta_{i} X_{i}+\varepsilon_{i} \quad \text { for } j=0,1 \\
P\left(I R_{i}>j\right)=\alpha_{i} \text { INTENDANTS' ARGUMENTS }+\beta_{i} X_{i}+\varepsilon_{i} \text { for } j=0,1 \\
P\left(D R_{i}>j\right)=\alpha_{i} \text { DÉPUTÉS' ARGUMENTS }+\beta_{i} X_{i}+\varepsilon_{i} \text { for } j=0,1 \\
P\left(F D_{i}>j\right)=\alpha_{i} \text { INTENDANTS' ARGUMENTS }+\beta_{i} X_{i}+\varepsilon_{i} \text { for } j=0,1 \\
P\left(F D_{i}>j\right)=\alpha_{i} \text { DÉPUTÉS' ARGUMENTS }+\beta_{i} X_{i}+\varepsilon_{i} \text { for } j=0,1
\end{gathered}
$$

where $F D_{i}, I R_{i}$, and $D R_{i}$ are the same variables as previously, and $X_{i}$ is the same vector of control variables (which includes Luxury, Foreigner, Year, and sector dummies).

Three different vectors of justifications include the most recurrent arguments put forward by respectively the Intendants, the Députés, and the final report sent to the Minister. As already shown in Table 1, each of them advanced many different arguments, though the size of our sample prevents us incorporating all of them separately in the regressions. Thus, we selected the arguments most frequently put forward by each party, that is, that were mentioned in more than 10 percent of the cases. This selection gives us a total of seven arguments for both Intendants and Députés, and nine for final decisions.

\footnotetext{
${ }^{17}$ As stressed by Williams (2006), there are two ways to circumvent the problem of a violated parallel-line assumption: an ordinal alternative (generalized ordered logistic model, or gologit) and/or non-ordinal alternative (multinomial logistic model, or mlogit). We use the gologit in order to maintain the ordinal structure of the dependent variable while being more parsimonious in terms of coefficient estimations and interpretation. Estimations run through mlogit models provide similar results but with a lower global significance of the models, giving us confidence for the relevance of using gologit estimations. Results are available on demand. See also Brant (1990).
} 


\section{EMPIRICAL RESULTS}

\section{The Respective Influences of Intendants and the Députés}

Table 2 provides the gologit estimations of the likelihood of obtaining privileges depending on the recommendations made respectively by the Députés and the Intendants. Models 1 and 2 present these estimates for each of these stakeholders taken separately. Model 3 takes both recommendations into account and Model 4 tests specifically for the presence of an informal "right of veto" by the Intendants and/or Députés.

A positive coefficient indicates that, other things equal, the independent variable makes it more likely that the request will receive the higher type of response; symmetrically, a negative coefficient means that the independent variable increases the probability of the request being in the current or a lower category of decision-making. As a consequence of the gologit methodology, the coefficients per se do not reflect marginal effects and cannot be interpreted in any specific manner. Their metric is however homogenous. Results are similar to the series of binary logistic regressions: that is, the first panel contrasts Category 0 (refusal) with Categories 1 and 2 (restriction and approval), whereas the second panel contrasts Categories 0 and 1 with Category 2 (full benefit) (Williams 2006).

These four gologit estimations first confirm that the stronger the endorsement of, respectively, the Intendants and the Députés, the higher the likelihood that the privileges will be approved (with or without restrictions). In other words, outsiders to the Bureau (courtiers, cliques, lobbies etc.) were not strong enough to derail its process and so to deliver outcomes systematically at odds with its internal deliberations.

In Model 1 and 2 the coefficients corresponding to variable $D R$ and IR respectively are thus always positive and statistically significant. They also indicate that the Députés and Intendants had a similar influence when deciding whether to reject a submission or give a privilege (first panels), whereas the former have a much bigger influence on the decision to grant or not the full privilege (second panels). The coefficients are of higher magnitude by a factor of 2.08 in Column " $0 ; 1 \rightarrow 2$. ." than in Column" $0 \rightarrow 1 ; 2$ ".

Model 3 confirms this broad conclusion on the basis of the sub-sample in which both parties' opinions are available. While the small number of observations (111) calls for a degree of caution, the results extends the earlier conclusion: the support of the Intendants is important when deciding whether to reject or not a submission, but their influence on the 
TABLE 2

FINAL DECISION AND RECOMMENDATIONS

\begin{tabular}{|c|c|c|c|c|c|c|c|c|}
\hline \multirow{3}{*}{$\begin{array}{l}\text { Dependent Variable: } \\
\text { Sample: } \\
\text { Models: }\end{array}$} & \multicolumn{8}{|c|}{ Final Decision (FD) } \\
\hline & \multicolumn{2}{|c|}{$\begin{array}{l}\text { Députés } \\
\text { (1) }\end{array}$} & \multicolumn{2}{|c|}{$\begin{array}{l}\text { Intendants } \\
\text { (2) }\end{array}$} & \multicolumn{2}{|c|}{$\begin{array}{l}\text { Both } \\
\text { (3) }\end{array}$} & \multicolumn{2}{|c|}{$\begin{array}{l}\text { Both } \\
\text { (4) }\end{array}$} \\
\hline & $0 \rightarrow 1 ; 2$ & $0 ; 1 \rightarrow 2$ & $0 \rightarrow 1 ; 2$ & $0 ; 1 \rightarrow 2$ & $0 \rightarrow 1 ; 2$ & $0 ; 1 \rightarrow 2$ & $0 \rightarrow 1 ; 2$ & $0 ; 1 \rightarrow 2$ \\
\hline DR & $\begin{array}{c}1.993 * * * \\
(0.374)\end{array}$ & $\begin{array}{c}4.146 * * * \\
(0.423)\end{array}$ & . & . & $\begin{array}{c}1.041^{* *} \\
(0.398)\end{array}$ & $\begin{array}{c}3.102 * * * \\
(0.529)\end{array}$ & . & . \\
\hline IR & . & . & $\begin{array}{c}1.968 * * * \\
(0.390)\end{array}$ & $\begin{array}{c}2.375 * * * \\
(0.479)\end{array}$ & $\begin{array}{c}1.246^{* *} \\
(0.418)\end{array}$ & $\begin{array}{c}1.261 \\
(0.779)\end{array}$ & . & . \\
\hline Veto-D & . & . & . & . & . & . & $\begin{array}{l}-0.855 \\
(0.937)\end{array}$ & $\begin{array}{c}-16.353^{* * *} \\
(0.596)\end{array}$ \\
\hline Veto-I & . & . & . & . & . & . & $\begin{array}{l}-1.171 \\
(1.009)\end{array}$ & $\begin{array}{l}-0.462 \\
(0.865)\end{array}$ \\
\hline Year & $\begin{array}{c}0.003 \\
(0.018)\end{array}$ & $\begin{array}{c}0.009 \\
(0.033)\end{array}$ & $\begin{array}{c}0.063 \\
(0.041)\end{array}$ & $\begin{array}{c}0.052 \\
(0.043)\end{array}$ & $\begin{array}{c}0.049 \\
(0.039)\end{array}$ & $\begin{array}{c}0.037 \\
(0.041)\end{array}$ & $\begin{array}{c}0.042 \\
(0.042)\end{array}$ & $\begin{array}{c}0.042 \\
(0.053)\end{array}$ \\
\hline Foreigner & $\begin{array}{c}0.793 \\
(0.824)\end{array}$ & $\begin{array}{c}0.468 \\
(1.413)\end{array}$ & $\begin{array}{c}0.014 \\
(0.745)\end{array}$ & $\begin{array}{c}-0.680+ \\
(0.412)\end{array}$ & $\begin{array}{c}0.965 \\
(1.095)\end{array}$ & $\begin{array}{c}0.734 \\
(1.331)\end{array}$ & $\begin{array}{c}0.272 \\
(0.797)\end{array}$ & $\begin{array}{c}0.353 \\
(0.889)\end{array}$ \\
\hline Luxury & $\begin{array}{l}-0.866 \\
(0.869)\end{array}$ & $\begin{array}{l}-0.704 \\
(0.625)\end{array}$ & $\begin{array}{l}-0.779 \\
(0.924)\end{array}$ & $\begin{array}{l}-1.314 \\
(0.897)\end{array}$ & $\begin{array}{l}-1.447 \\
(1.400)\end{array}$ & $\begin{array}{c}-14.874 * * * \\
(0.800)\end{array}$ & $\begin{array}{l}-1.159 \\
(1.216)\end{array}$ & $\begin{array}{c}-16.779 * * * \\
(0.722)\end{array}$ \\
\hline Sector & \multicolumn{2}{|c|}{ Yes } & \multicolumn{2}{|c|}{ Yes } & \multicolumn{2}{|c|}{ Yes } & \multicolumn{2}{|c|}{ Yes } \\
\hline Intercept & $\begin{array}{c}-7.022 \\
(31.896)\end{array}$ & $\begin{array}{l}-21.922 \\
(57.924)\end{array}$ & $\begin{array}{c}-110.653 \\
(71.072)\end{array}$ & $\begin{array}{l}-95.117 \\
(74.807)\end{array}$ & $\begin{array}{l}-86.380 \\
(67.157)\end{array}$ & $\begin{array}{l}-71.655 \\
(70.710)\end{array}$ & $\begin{array}{l}-71.247 \\
(73.104)\end{array}$ & $\begin{array}{l}-73.581 \\
(91.159)\end{array}$ \\
\hline Adj. $R^{2}$ & \multicolumn{2}{|c|}{0.43} & \multicolumn{2}{|c|}{0.26} & \multicolumn{2}{|c|}{0.40} & \multicolumn{2}{|c|}{0.10} \\
\hline $\mathrm{N}$ & \multicolumn{2}{|c|}{215} & \multicolumn{2}{|c|}{136} & \multicolumn{2}{|c|}{111} & \multicolumn{2}{|c|}{111} \\
\hline
\end{tabular}

Notes: Standard errors, clustered at the regional level, are reported in parentheses. ${ }^{* * *} \mathrm{p}<0.001, * * \mathrm{p}<0.01, * \mathrm{p}<0.05,+\mathrm{p}<0.1$

Source: Authors' calculations. 
TABLE 3

FINAL DECISION AND DÉPUTÉS' AND INTENDANTS' RECOMMENDATIONS: PREDICTED PROBABILITIES

\begin{tabular}{llccc}
\hline \hline \multicolumn{2}{c}{ Predicted Probability: } & $\begin{array}{c}\mathrm{P}(F D=0) \\
\text { Refusal }\end{array}$ & $\begin{array}{c}\mathrm{P}(F D=1) \\
\text { Restriction }\end{array}$ & $\begin{array}{c}\mathrm{P}(F D=2) \\
\text { Approval }\end{array}$ \\
\hline \multirow{2}{*}{$I R$} & 0 (refusal) & 49.8 & 23.6 & 8.2 \\
& 1 (restriction) & 45.1 & 65.2 & 58.1 \\
& 2 (approval) & 5.1 & 11.2 & 33.7 \\
DR (refusal) & 40.2 & 19.2 & 7.7 \\
& 1 (restriction) & 59.4 & 72.4 & 25 \\
& 2 (approval) & 0.4 & 8.4 & 67.3 \\
\hline
\end{tabular}

Source: Authors' calculations.

likelihood of giving the entire package of privileges is not statistically significant. The opinion of Députés, on the other hand, weighs on both options though more strongly when they recommend or not a full grant. Model 4 then shows that the sign associated with the coefficient Veto-D (veto right by the Députés) is negative and significant while the sign of the variable Veto-I (veto right by the Intendent) is not statistically significant. This result suggests that a disagreement between the two types of experts is prohibitive when the Députés recommend rejection against the preference of the Intendant, though the reverse is not true.

In order to make these effects more "substantial," the predicted probabilities from the first model "Both" (Column 3 of Table 2) have been calculated. Table 3 indicates that when the Intendant recommend that the entire set of privileges be granted, the Bureau follows their advice in 33.7 percent of cases and rejects the request in only 5.1 percent of them. In the case of the Députés, these probabilities are respectively 67.3 percent and 0.4 percent.

Finally, regarding the control variables Year and Foreigner, in Table 2 have no effect. The variable Luxury on the other hand has a significant, negative impact in Models 3 and 4, though exclusively when deciding for a full grant. This last result should be taken with caution as among the 27 requests for privileges concerning luxury goods, only five are included in the sample Both, and none of those projects was entirely granted. Still, the overall result runs clearly counter to the common assumption, repeated since the time of Eli Heckscher (1931), that the French version of mercantilism was strongly biased toward serving the demands of the upper classes. This may have been the case under Colbert (1661-1683), but the pattern is absent during the period under review. 


\section{The Motivations of Opinions and Decisions}

In the second series of tests, we assess to which extent specific qualitative arguments for or against each submission had a particular impact on the final decisions. With this view, we regress the same independent variable as previously $(F D)$ on the nine arguments that were most often leveraged by the Bureau as a whole (second college) when making a final decision on each project. For instance, TradeBalance takes Value 1 when the final product was seen as having a positive potential impact on import reduction. The same holds for contributions to the local economy (Local economy), technical innovation (Technic.innovation), competition issues (Restric.competition), etc.

The results reported in Model 1 of Table 4 are straightforward: all things being equal, the Bureau was more willing to grant privileges when the quality of the production (Quality) was expected to be high, when the investment would benefit the local economy and the consumers (Consumer), when technical innovation was at stake and when a positive contribution to the trade balance was anticipated. On the other hand, the Bureau was less prone to grant privileges when the project was likely to distort competition or when the underlying technology (No.innovation) was seen as already well known.

\section{Who Raised Which Argument, and to What Effect?}

The last question is whether the weight of these different substantive arguments was affected by the person who raised them, i.e. the Intendant or the Députés. So we estimate the impact of the arguments they use, first on their own recommendations, then on the final collective decision, as sent to the Minister (Models 2 to 5 in Table 4).

Model 2 indicates that the provincial Intendants were more willing to support a project when the quality of products was expected to be good and when it was deemed to have a positive effect on local consumers; to a lesser extent, the Intendants cared with the exploitation of local resources, with large investments (Sunkcost) and with the trade balance. On the negative side, they were keen to avoid market distortions. Model 4 then shows that the Députés were also prone to lend support to a project that was expected to benefit the local economy, the consumers and the trade balance. But they were also looking closely at issues of competition, technical innovation and quality of products. 
TABLE 4

ACTORS’ ARGUMENTS AND INFLUENCE ON RECOMMENDATIONS AND FINAL DECISION

\begin{tabular}{|c|c|c|c|c|c|c|c|c|c|c|}
\hline \multirow{4}{*}{$\begin{array}{l}\text { Dependent Variable: } \\
\text { Arguments raised by: } \\
\text { Models: }\end{array}$} & \multicolumn{2}{|c|}{ Final Decision } & \multicolumn{2}{|c|}{ Intendants' Recommendations } & \multicolumn{2}{|c|}{ Final Decision } & \multicolumn{2}{|c|}{ Députés' Recommendations } & \multicolumn{2}{|c|}{ Final Decision } \\
\hline & \multicolumn{2}{|c|}{ Bureaucrats } & \multicolumn{4}{|c|}{ Intendants } & \multicolumn{4}{|c|}{ Députés } \\
\hline & \multicolumn{2}{|c|}{$(1)$} & \multicolumn{2}{|c|}{$(2)$} & \multicolumn{2}{|c|}{ (3) } & \multicolumn{2}{|c|}{ (4) } & \multicolumn{2}{|c|}{$(5)$} \\
\hline & $0 \rightarrow 1 ; 2$ & $0 ; 1 \rightarrow 2$ & $0 \rightarrow 1 ; 2$ & $0 ; 1 \rightarrow 2$ & $0 \rightarrow 1 ; 2$ & $0 ; 1 \rightarrow 2$ & $0 \rightarrow 1 ; 2$ & $0 ; 1 \rightarrow 2$ & $0 \rightarrow 1 ; 2$ & $0 ; 1 \rightarrow 2$ \\
\hline Quality $^{+}$ & $\begin{array}{c}2.815^{* *} \\
(0.904)\end{array}$ & $\begin{array}{l}0.877^{*} \\
(0.404)\end{array}$ & $\begin{array}{c}18.051^{* * *} \\
(1.606)\end{array}$ & $\begin{array}{c}2.158 * * * \\
(0.607)\end{array}$ & $\begin{array}{c}0.225 \\
(0.681)\end{array}$ & $\begin{array}{c}0.364 \\
(0.382)\end{array}$ & $\begin{array}{l}1.613^{*} \\
(0.700)\end{array}$ & $\begin{array}{c}0.414 \\
(0.438)\end{array}$ & $\begin{array}{c}0.736+ \\
(0.441)\end{array}$ & $\begin{array}{c}0.151 \\
(0.397)\end{array}$ \\
\hline Trade balance. & $\begin{array}{c}19.148 * * * \\
(0.619)\end{array}$ & $\begin{array}{c}0.213 \\
(0.385)\end{array}$ & $\begin{array}{c}0.207 \\
(1.459)\end{array}$ & $\begin{array}{c}1.075 \\
(0.804)\end{array}$ & $\begin{array}{c}0.969 \\
(0.745)\end{array}$ & $\begin{array}{c}0.046 \\
(0.509)\end{array}$ & $\begin{array}{l}2.361^{*} \\
(1.078)\end{array}$ & $\begin{array}{c}0.503 \\
(0.314)\end{array}$ & $\begin{array}{c}2.088^{* *} \\
(0.669)\end{array}$ & $\begin{array}{l}0.521+ \\
(0.302)\end{array}$ \\
\hline Local economy $^{+}$ & $\begin{array}{c}20.258 * * * \\
(0.395)\end{array}$ & $\begin{array}{c}1.217 * * * \\
(0.310)\end{array}$ & $\begin{array}{c}2.862 * * \\
-0.447\end{array}$ & $\begin{array}{l}1.136+ \\
(0.584)\end{array}$ & $\begin{array}{l}0.686^{*} \\
(0.326)\end{array}$ & $\begin{array}{l}0.665^{*} \\
(0.314)\end{array}$ & $\begin{array}{c}17.717^{* * * *} \\
(0.504)\end{array}$ & $\begin{array}{c}0.587 \\
(0.384)\end{array}$ & $\begin{array}{c}0.728 \\
(0.548)\end{array}$ & $\begin{array}{c}0,492 \\
(0.471)\end{array}$ \\
\hline Consumer $^{+}$ & $\begin{array}{c}2.940 * * \\
(0.919)\end{array}$ & $\begin{array}{c}1.559 * * * \\
(0.457)\end{array}$ & $\begin{array}{c}16.879 * * * \\
(0.894)\end{array}$ & $\begin{array}{l}1.586^{*} \\
(0.772)\end{array}$ & $\begin{array}{c}0.529 \\
(0.667)\end{array}$ & $\begin{array}{c}0.589 \\
(0.515)\end{array}$ & $\begin{array}{l}2.555^{*} \\
(1.137)\end{array}$ & $\begin{array}{l}1.273^{* *} \\
(0.488)\end{array}$ & $\begin{array}{l}0.655+ \\
(0.367)\end{array}$ & $\begin{array}{c}0.225 \\
(0.377)\end{array}$ \\
\hline Sunkcosts & $\begin{array}{c}17.897 * * * \\
(1.152)\end{array}$ & $\begin{array}{c}0.375 \\
(0.379)\end{array}$ & $\begin{array}{c}16.237 * * * \\
(1.581)\end{array}$ & $\begin{array}{l}-0.944 \\
(0.806)\end{array}$ & $\begin{array}{c}0.713 \\
(1.031)\end{array}$ & $\begin{array}{l}-0.405 \\
(0.586)\end{array}$ & - & - & - & - \\
\hline Technic.innovation & $\begin{array}{c}1.760^{* *} \\
(0.667)\end{array}$ & $\begin{array}{l}0.625+ \\
(0.363)\end{array}$ & - & - & - & - & $\begin{array}{c}2.076^{* * * *} \\
(0.274)\end{array}$ & $\begin{array}{c}0.237 \\
(0.454)\end{array}$ & $\begin{array}{c}0.100 \\
(0.706)\end{array}$ & $\begin{array}{c}0.213 \\
(0.464)\end{array}$ \\
\hline Restrict.competition & $\begin{array}{l}-0.165 \\
(0.454)\end{array}$ & $\begin{array}{c}-3.153 * * * \\
(0.765)\end{array}$ & $\begin{array}{c}-1.371 * * \\
(0.426)\end{array}$ & $\begin{array}{c}-2.946^{* *} \\
(0.980)\end{array}$ & $\begin{array}{l}-0.203 \\
(0.368)\end{array}$ & $\begin{array}{c}-1.960^{*} \\
(0.788)\end{array}$ & $\begin{array}{c}-0.869^{*} \\
(0.435)\end{array}$ & $\begin{array}{c}-17.570^{* * *} \\
(0.371)\end{array}$ & $\begin{array}{c}-0.761^{*} \\
(0.360)\end{array}$ & $\begin{array}{c}-2.058 * * * \\
(0.476)\end{array}$ \\
\hline Val.local.resources & $\begin{array}{c}18.662 * * * \\
(1.159)\end{array}$ & $\begin{array}{c}0.590 \\
(0.417)\end{array}$ & $\begin{array}{l}-0.189 \\
(1.608)\end{array}$ & $\begin{array}{l}1.944^{*} \\
(0.762)\end{array}$ & $\begin{array}{c}0.725 \\
(0.459)\end{array}$ & $\begin{array}{c}0.262 \\
(0.392)\end{array}$ & - & - & - & - \\
\hline No.innovation & $\begin{array}{l}-0.378 \\
(0.338)\end{array}$ & $\begin{array}{c}-19.574 * * * \\
(0.450)\end{array}$ & - & - & - & - & $\begin{array}{c}-1.902 * * \\
(0.613)\end{array}$ & $\begin{array}{c}-16.936 * * * \\
(0.457)\end{array}$ & $\begin{array}{c}-0.647+ \\
(0.338)\end{array}$ & $\begin{array}{c}-2.900^{* *} \\
(1.092)\end{array}$ \\
\hline Controls & \multicolumn{2}{|c|}{ Yes } & \multicolumn{2}{|c|}{ Yes } & \multicolumn{2}{|c|}{ Yes } & \multicolumn{2}{|c|}{ Yes } & \multicolumn{2}{|c|}{ Yes } \\
\hline Intercept & $\begin{array}{c}-1.364 * * * \\
(0.345)\end{array}$ & $\begin{array}{c}-1.672 * * * \\
(0.279)\end{array}$ & $\begin{array}{l}-0.055 \\
(0.409)\end{array}$ & $\begin{array}{l}-0.602 \\
(0.504)\end{array}$ & $\begin{array}{c}0.627 \\
(0.428)\end{array}$ & $\begin{array}{l}-0.679 \\
(0.452)\end{array}$ & $\begin{array}{c}0.101 \\
(0.433)\end{array}$ & $\begin{array}{c}-0.687+ \\
(0.366)\end{array}$ & $\begin{array}{l}0.529+ \\
(0.301)\end{array}$ & $\begin{array}{c}-0.822^{*} \\
(0.359)\end{array}$ \\
\hline Adj. $R^{2}$ & \multicolumn{2}{|c|}{0.42} & \multicolumn{2}{|c|}{0.34} & \multicolumn{2}{|c|}{0.10} & \multicolumn{2}{|c|}{0.41} & \multicolumn{2}{|c|}{0.19} \\
\hline $\mathrm{N}$ & \multicolumn{2}{|c|}{267} & \multicolumn{2}{|c|}{136} & \multicolumn{2}{|c|}{136} & \multicolumn{2}{|c|}{215} & \multicolumn{2}{|c|}{215} \\
\hline
\end{tabular}

Notes: "Controls" include the variable year, foreigner, luxury and sector dummies. Standard errors, clustered at the regional level, are reported in parentheses. ${ }^{* * *}<<0.001,{ }^{* *} \mathrm{p}<0.01,{ }^{*} \mathrm{p}<0.05,+\mathrm{p}<0.1$. Source: Authors' calculations. 
A rather nuanced picture emerges from these results, when taken all together. First, the benefits to the local economy and to the consumers, plus the quality of products bear on both decisions - whether or not to reject entirely a submission, and whether or not to give a full privilege. Hence, they come out as the dominant motives in this early industrial policy, with the Intendants and the Députés in broad agreement here. On the other hand, the trade balance, the local resources and the sunk costs arguments only weighed on the decision whether to give benefits, but did not affect the decision to give the full privilege. At that point, competition and the innovative character of the project seem to have dominated the decision, though only in a negative way: when raised, especially by the Députés, these arguments apparently opposed a strong bar against a positive decision, though in turn they would not necessarily predict full rejection.

One possible interpretations of the superior influence of the Députés is that their collegial character endowed them with greater expertise, hence with more credibility. Moreover, their professional experience may have given them a broader vision of the market and the underlying policy issues. The Intendant was an individual participant who only contributed written reports, without attending directly the Parisian meetings. The Intendants had a more local and uneven understanding, for instance, of the technology or the competition. At least, this is the impression given by the comparative reading of their respective Avis.

\section{CONCLUSION}

This article has explored how a small eighteenth-century French agency followed formal, predictable and impersonal rules in order to allocate (or refuse) packages of benefits to hundreds of private entrepreneurs from 1724 to 1744 . In a context where no signal of systematic self-selection by applicants was observed, our most remarkable result is the overall consistency of these rules, given both the very small size of the Bureau du Commerce and the thoroughly rent-seeking character of the Ancien Régime monarchy. Even within its closed doors, different types of expertise did not have the same influence on outcomes.

Moroever, some policies, conducted in parallel with the one we studied, did not show this pattern of relative procedural autonomy (Graber 2011 and Szulman 2011). This suggests strongly that when exploring 
bureaucratic modernization, one should look at specific policy lines, their respective procedures and the type of interests they mobilize before evaluating their potential for impersonal decision making.

The Bureau du Commerce organized decision making around a rather sophisticated collegial structure that worked de facto as a substitute for a political mechanism of interest representation with a legislature as the place where policy decisions are made (O'Brien, Griffiths, and Hunt 1991). This bureaucratic mechanism reflects, of course, the fact that, under the Ancien Régime, sovereignty was not shared with the people. But it also responds to the intense legal and institutional fragmentation of the kingdom that made highly difficult the adoption of policies that would apply uniformly across the whole country (Epstein 2000).

The broader lesson is that progress towards law-based, impersonal public administrations should not necessarily proceed top-down, that is, through broad changes in the political regime that then lead to redesigning the control mechanism of the state machinery as a whole. The experience examined here suggests that even under a classic absolutist monarchy, public administrations could be much more fluid, diverse, and open to experimentation than is often assumed. This may be in particular a defining feature of enlightened despotism. 


\section{Appendix 1 \\ Variables, Definitions, and Summary Statistics}

\begin{tabular}{|c|c|c|}
\hline Variables & Definitions & $\begin{array}{l}\text { Summary } \\
\text { Statistics }\end{array}$ \\
\hline FD (final decision) & $\begin{array}{l}\text { Ordinal variable which indicates the final decision made by } \\
\text { the Bureau. Applications could be rejected }(\boldsymbol{F D}=0) \text {, could } \\
\text { be partially granted }(\boldsymbol{F D}=1) \text { or the entire set of privileges } \\
\text { could be handed out }(\boldsymbol{F D}=2)\end{array}$ & $\begin{aligned} 0 & : 76(28.5 \%) \\
1 & : 78(29.2 \%) \\
2: & 113(42.3 \%) \\
& \mathrm{N}=267\end{aligned}$ \\
\hline $\begin{array}{l}\text { IR (intendants' } \\
\text { recommendations) }\end{array}$ & $\begin{array}{l}\text { Ordinal variable which indicates the recommendations made } \\
\text { by the provincial Intendants for the final decision (same } \\
\text { construction as } \boldsymbol{F D} \text { above). }\end{array}$ & $\begin{array}{c}0: 20(14.7 \%) \\
1: 27(19.9 \%) \\
2: 89(65.4 \%) \\
N=136\end{array}$ \\
\hline $\begin{array}{l}\text { DR (députés' } \\
\text { recommendations) }\end{array}$ & $\begin{array}{l}\text { Ordinal variable which indicates the recommendations made } \\
\text { by the Députés for the final decision (same construction as } \\
\boldsymbol{F D} \text { above). }\end{array}$ & $\begin{array}{c}0: 58(27 \%) \\
1: 68(31.6 \%) \\
2: 89(41.4 \%) \\
N=215\end{array}$ \\
\hline Veto-I & $\begin{array}{l}\text { Dummy variable which is equal to } 1 \text { when the local } \\
\text { Intendants recommend refusal while the Députés claim for } \\
\text { restrictive or full grant of the privileges. }\end{array}$ & $\begin{array}{l}0: 106(95.5 \%) \\
1: 5(4.5 \%) \\
\mathrm{N}=111\end{array}$ \\
\hline Veto-D & $\begin{array}{l}\text { Dummy variable which is equal to } 1 \text { when the Députés } \\
\text { recommend refusal while local Intendants claim for } \\
\text { restrictive or full grant of the privileges. }\end{array}$ & $\begin{array}{l}0: 106(95.5 \%) \\
1: 5(4.5 \%) \\
\mathrm{N}=111\end{array}$ \\
\hline Luxury & $\begin{array}{l}\text { Dummy variable which is equal to } 1 \text { if the application is } \\
\text { concerning a luxury product. }\end{array}$ & $\begin{array}{c}0: 244(91.4 \%) \\
1: 23(8.6 \%) \\
N=267\end{array}$ \\
\hline Foreigner & $\begin{array}{l}\text { Dummy variable which is equal to } 1 \text { if the application is } \\
\text { made by a foreign entrepreneur. }\end{array}$ & $\begin{array}{c}0: 250(93.6 \%) \\
1: 17(6.4 \%) \\
N=267\end{array}$ \\
\hline Year & Date of the application. & $\begin{array}{l}m=1732.6 \\
\sigma=6.1\end{array}$ \\
\hline \multirow[t]{13}{*}{ Sector } & Sector of the application: & \\
\hline & Food & $6(2.1 \%)$ \\
\hline & Faience & $22(7.8 \%)$ \\
\hline & Forge & $5(1.8 \%)$ \\
\hline & Machine & $18(6.4 \%)$ \\
\hline & Metal & $20(7.1 \%)$ \\
\hline & Mine & $13(4.6 \%)$ \\
\hline & Mill & $16(5.7 \%)$ \\
\hline & Small manufacturing & $10(3.6 \%)$ \\
\hline & Service & $5(1.8 \%)$ \\
\hline & Dye & $22(7.8 \%)$ \\
\hline & Textile & $108(38.4 \%)$ \\
\hline & Glass & $36(12.8 \%)$ \\
\hline
\end{tabular}


Arguments

Custom and common practices +

Custom and common Practices-

Precedents +

Precedents -

Statutes and royal decrees +

Statutes and royal decrees -

Trade balance

Local economy+

Local economy-

Consumer+

Consumer-

Technical innovation

Quality+

Quality-

Fixed costs

Attract labor force

Valorization of local resources

Social employment

Provision of public good
Arguments put forward by applicants / Bureaucrats/ Intendants / Députés:

$\begin{array}{ll}\begin{array}{l}\text { References to practices and factual } \\ \text { situations which are not necessarily }\end{array} & \begin{array}{l}\text { See Table } 2 \text { for the } \\ \text { descriptive statistics }\end{array}\end{array}$
codified.

Here, and below for all, "-" refers to the same argument used to deny or curtail asked privileges.

Reference to similar previous privileges granted to a third party.

Cf. above.

Law and jurisprudence on which the applicant or council relies (outside, of course, the jurisprudence about privileges).

Cf. above.

Development of production for the domestic market (substitution of imports) and for the development of exports.

Arguments that insist on the dimension of economic activity and/ or market size and demand support. The important point here is the local/regional development character.

Cf. above.

Explicit reference to the price and/or quality in a logical demand side and utility for consumers (usually local).

Cf. above

Invention or import of a foreign technology not yet available in France.

All the arguments that refer to the quality of production and unique know-how that have been developed by the contractor and should be protected (not technology, coded as "Technical Innovation" above).

All the arguments that refer to the fact that the production quality and/or skills are low and do not (or no longer) warrant protection. It is not know-how and technologies that have become commonplace, but explicitly poor performance.

Arguments that refer to the fact that significant financial and/or human investment has been made.

A needs to draw in the workforce, both for local and foreign workforce (always for skilled workers).

Valorization of material and natural resources.

Arguments that refer to the fact that the population of the region in general will gain better work, especially for poor and hospital residents. The argument is different from the "Local Economy +" in the sense that the problem of absorption of underemployment must be explicitly mentioned.

Arguments that refer to the fact that the proposed product/service corresponding to the application is a response to a market failure: production of "public infrastructure"/provision of "public services." 


\section{State Support to Private Firms in 18th-Century France 1173}

\begin{tabular}{|c|c|}
\hline Arguments & $\begin{array}{l}\text { Arguments put forward by applicants / Bureaucrats/ Intendants / } \\
\text { Députés: }\end{array}$ \\
\hline Reducing fraud & $\begin{array}{l}\text { Arguments that refer to the fact that the proposed product/service } \\
\text { corresponding to the application is a response to a regulatory failure } \\
\text { or a failure of enforcement of standards (quality of production, } \\
\text { taxation, foreign trade). This is often a proposal to check the } \\
\text { crossings (roads, warehouses, etc.). }\end{array}$ \\
\hline Industrial risk & $\begin{array}{l}\text { Arguments put forward when there is uncertainty about the feasibility } \\
\text { of the project or the idea seems too risky. }\end{array}$ \\
\hline Difficulty of implementation & $\begin{array}{l}\text { Arguments put forward when the privilege could not produce } \\
\text { the desired effects in terms of support to the project and/or its } \\
\text { enforcement would be problematic. }\end{array}$ \\
\hline Restriction of competition & $\begin{array}{l}\text { Arguments that refer to the fact that granting a privilege would give } \\
\text { an unfair advantage to a competitor or create a distortion which } \\
\text { would prove to be inefficient in terms of competitive selection } \\
\text { (including fiscal distortion). }\end{array}$ \\
\hline Absence of innovation & $\begin{array}{l}\text { Arguments put forward when the knowledge associated to the } \\
\text { application is already well known. }\end{array}$ \\
\hline Risk of overproduction & $\begin{array}{l}\text { Arguments that refer to the fact that granting a privilege would } \\
\text { lead to excessively lowering the marginal returns of capital already } \\
\text { invested or that it does not appear relevant to favor new entries. }\end{array}$ \\
\hline Prior property rights infringement & Interference with prior property rights (i.e., with other privileges). \\
\hline Fiscal costs & Calculation cost/benefit to the State. \\
\hline Fiscal fairness & $\begin{array}{l}\text { Arguments that refer to the simple fact that it appears unfair to favor } \\
\text { certain professions/industries/populations compared to others. It } \\
\text { refers to all cases where an exemption seems unjustified in terms of } \\
\text { the "equality of subjects before the tax." }\end{array}$ \\
\hline Lack of Realization & $\begin{array}{l}\text { Situation where the privilege is explicitly removed or canceled for } \\
\text { lack of the exercise of a privilege granted in the past. }\end{array}$ \\
\hline Uncertainty/incompleteness & $\begin{array}{l}\text { It does not refer to additional investigations in the case of incomplete } \\
\text { information, but rather where the projects are too hazy and vague so } \\
\text { it is impossible to determine either the benefits or the costs and risks } \\
\text { (unlike the case of projects identified as "too risky"). }\end{array}$ \\
\hline
\end{tabular}

\section{REFERENCES}

Antoine, Michel. Le Conseil Royal des Finances au XVIII ${ }^{\circ}$ siècle et le registre E3659 des Archives Nationales. Genève: Droz, 1973.

- "La notion de subdélégation dans la monarchie d'Ancien Régime." Bibliothèque de l'école des chartes 132, no. 2 (1974): 267-87.

. Le cœur de l'Etat. Surintendance, contrôle général et intendances des finances, 1552-1791. Paris: Fayard, 2003.

Beuve, Jean, Eric Brousseau, and Jérôme Sgard. "Mercantilism and Bureaucratic Modernization in Eighteenth Century France." Economic History Review 70, no. 2 (2017): 529-58. 
Biollay, Léon. Etudes Economiques sur le xviii ${ }^{\circ}$ siècle. Paris: Guillaumin, 1885.

Bonnassieux, Pierre. Conseil de commerce et bureau de commerce: 1700-1790: inventaire analytique des process-verbaux. Paris: Imprimerie Nationale, 1900.

Bosher, John Francis. French Finances, 1770-1795 - from Business to Bureaucracy. Cambridge: Cambridge University Press, 1970.

Bossenga, Gail. The Politics of Privilege. Old Regime and Revolution in Lille. Cambridge: Cambridge University Press, 1991.

Brant, Rollin. "Assessing Proportionality in the Proportional Odds Model for Ordinal Logistic Regression." Biometrics 46, no. 4 (1990): 1171-78.

Brewer, John. The Sinews of Power: War, Money, and the English State, 1688-1783. New York: Alfred Knopf, 1989.

Campbell, Peter Robert. Power and Politics in Old Regime France, 1720-1745. London: Routledge, 1996.

Cole, Charles Woolsey. French Mercantilism, 1683-1700. New York: Columbia University Press, 1943.

Comité pour l'histoire économique et financière de la France. L'administration des finances sous l'Ancien Régime. Paris: Comité pour l'histoire économique et financière de la France, 1997.

Cosandey, Fanny, and Robert Descimon. L'absolutisme en France, Histoire et Historiographie. Paris: Le Seuil, 2002.

Ekelund, Robert B., and Robert Tollison. Mercantilism and Rent-Seeking Society. College Station: Texas A\&M University Press, 1981.

- Politicized Economies: Monarchy, Monopoly, and Mercantilism. College Station: Texas A\&M University Press, 1989.

Epstein, Stephan R. Freedom and Growth. The Rise of States and Markets in Europe, 1300-1750. London: Routledge, 2000.

Felix, Joël. 1997. "Les commis du Contrôle général des finances au xviii ${ }^{\circ}$ siècle." In L'Administration des finances sous l'Ancien Régime, Colloque tenu à Bercy les 22 et 23 février 1996. Paris: Comité pour l'histoire économique et financière de la France, 1997.

Finer, Samuel Edwards. The History of Government from the Earliest Times, vol. 3. Oxford: Oxford University Press, 1997.

Foucault, Michel. Sécurité, Territoire, Population. Cours au Collège de France, 19771978. Paris: Gallimard and Seuil, 2004.

Fournier, Joseph. La Chambre de commerce de Marseille et ses représentants permanents à Paris (1599-1875). Marseille: Barlatier, 1920.

$\mathrm{Fu}$, Vincent. “Estimating Generalized Ordered Logit Models.” Stata Technical Bulletin Reprints 8 (1998): 160-64.

Garrigues, Frédéric. "Les Intendants du Commerce au xviii ${ }^{\circ}$ siècle." Revue d'Histoire Moderne et Contemporaine 45, no. 3 (1998): 626-61.

Graber, Fréderic. "Du faiseur de projet au projet régulier dans les Travaux Publics (XVIII ${ }^{\mathrm{e}}-\mathrm{XIX}{ }^{\mathrm{e}}$ siècles): pour une histoire des projets." Revue d'Histoire Moderne et Contemporaine 58, no. 3 (2011): 7-33.

Heckscher, Eli. Mercantilism. London: Routledge, 1994/1931.

Hintze, Otto. The Commissary and His Significance in General Administrative History. In Historical Essays of Otto Hintze. New York: Oxford University Press, 1975/1919. 


\section{State Support to Private Firms in 18th-Century France 1175}

Hoffman, Philip T. "What Do States Do? Politics and Economics History." Journal of Economic History 75, no. 2 (2015): 303-32.

Horn, Jeff. Economic Development in Early Modern France: The Privilege of Liberty, 1650-1820. Cambridge: Cambridge University Press, 2015.

Hutteau d'Origny, Antoine-François. Histoire du Bureau du Commerce et du Conseil royal des finances et du commerce. Paris: Unknown publisher, 1857.

Kessler, Amalia D. A Revolution in Commerce: The Parisian Merchant Court and the Rise of Commercial Society in Eighteenth-Century France. New Haven, CT: Yale University Press, 2007.

Kettering, Sharon. Patrons, Brokers, and Clients in Seventeenth-Century France. Oxford: Oxford University Press, 1986.

Labraque-Bordenave, V. Histoire des députés de Bordeaux au conseil de commerce, 1700-1793. Actes de l'académie des sciences, arts et belles-lettres de Bordeaux. $51,1889$.

Lazega, Emmanuel. The Collegial Phenomenon: The Social Mechanisms of Cooperation Among Peers in a Corporate Law Partnership. Oxford: Oxford University Press, 2001.

Minard, Philippe. La fortune du colbertisme. Etat et industrie dans la France des Lumières. Paris: Fayard, 1998.

Moore, Barrington. Social Origins of Dictatorship and Democracy: Lord and Peasant in the Making of the Modern World. Boston: Beacon Press, 1966.

Mousnier, Roland. "Les fidélités et les clientèles en France au xvi ${ }^{\circ}$, xvii ${ }^{\circ}$ et xviii siècles." Histoire Sociale/ Social History 15 (1982): 35-46.

O' Brien, Patrick, Trevor Griffiths, and Philip Hunt. "Political Components of the Industrial Revolution: Parliament and the English Cotton Textile Industry, 1660 1774." Economic History Review 44, no. 3 (1991): 395-423.

Parker, Harold T. The Bureau of Commerce in 1781 and Its Policies with Respect to French Industry. Durham: Carolina Academic Press, 1979.

Pariset, Ernest. La Chambre de commerce de Lyon au dix-huitième siècle: étude faite sur les registres de ses délibérations. Mémoires de l'Académie des sciences, belleslettres, et arts de Lyon. 24, 1887.

Quenet, Maurice. "Un exemple de consultation dans l'administration monarchique au XVIII siècle, Les Nantais et leurs Députés au Conseil du Commerce.” Annales de Bretagne 85 (1978): 449-85.

Ricommard, Julien. "Les subdélégués des intendants aux xvii ${ }^{\circ}$ et xviii ${ }^{\circ}$ siècles." L'information historique (1962): 139-48.

—. "Les subdélégués des intendants aux xvii ${ }^{\circ}$ et xviii ${ }^{\circ}$ siècles." L'information historique 190-5 (1963): 1-7.

Root, Hilton L. The Fountain of Privilege: Political Foundations of Markets in Old Regime France and England. Berkeley: University of California Press, 1994.

Rothkrug, Lionel. Opposition to Louis XIV: The Political and Social Origins of French Enlightenment. Princeton: Princeton University Press, 1965.

Schaeper, Thomas J. The French Council of Commerce, 1700-175: A Study of Mercantilism after Colbert. Columbus: Ohio State University Press, 1983.

Skocpol, Theda. States and Social Revolutions. A Comparative Analysis of France, Russia, and China. New York: Cambridge University Press, 1978 [2013 reprint]. 
Smith, David K. “'Au Bien du Commerce': Economic Discourse and Visions of Society on France.” Ph.D. diss., University of Michigan, 1995.

- "Structuring Politics in Early Eighteenth-Century France: The Political Innovations of the French Council of Commerce." Journal of Modern History 74, no. 3 (2002): 490-537.

Spruyt, Hendrik. The Sovereign State and Its Competitors. An Analysis of System Change. Princeton: Princeton University Press, 1994.

Strayer, Joseph R. On the Medieval Origins of the Modern State. Princeton: Princeton University Press, 1970 [2005 reprint].

Szulman, Eric. "Savoir administratif et construction de l'espace fluvial français du XVIIème siècle au XIXème siècle." Thèse d'Etat, Paris: Université de Paris-4, 2011.

Tilly, Charles. Coercion, Capital, and European States, AD 990-1992. Malden, MA: Blackwell, 1990.

Tocqueville, Alexis de. The Old Regime and the Revolution. Chicago: University of Chicago Press, 2012 (original edition 1859).

Wallerstein, I. The Modern World-System, II: Mercantilism and the Consolidation of the European World-Economy, 1600-1750. New York: Academic Press, 1980.

Waters, Malcolm. "Collegiality, Bureaucratization, and Professionalization: A Weberian Analysis." American Journal of Sociology 94, no. 5 (1989): 945-72.

—. "Alternative Organizational Formations: A Neo-Weberian Typology of Polycratic Administrative Systems." Sociological Review 41, no. 1 (1993): 55-81.

Weber, Max. Economy and Society, vol. 2. Berkeley: University of California Press, 1978 (original edition 1920).

Williams, Richard. "Generalized Ordered Logit / Partial Proportional Odds Models for Ordinal Dependent Variables.” Stata Journal 6, no. 1 (2006): 58-82.

Wybo, Bernard. Le Conseil de commerce et le commerce intérieur de la France au XVIIIe siècle, thèse pour le doctorat. Paris: F. Loviton, 1936. 